\title{
Upaya pemerintah desa dalam mengatasi perilaku sosial masyarakat yang menggantungkan diri terhadap pemberian orang lain
}

\author{
Erlita Kurniawati Sari, ${ }^{a, 1}$ Susena ${ }^{\text {b,,2 }}$ \\ a Program Studi PPKn, Universitas Ahmad Dahlan, Yogyakarta \\ ${ }^{\mathrm{b}}$ Program Studi PPKn, Universitas Ahmad Dahlan, Yogyakarta \\ 1 erlita12009029@webmail.uad.ac.id²susena@ppkn.uad.ac.id \\ * korespondensi penulis
}

\begin{abstract}
ABSTRAK
Desa Pageralang Kecamatan Kemranjen Kabupaten Banyumas memiliki tradisi kontra sosial secara turun temurun yaitu melakukan kegiatan meminta-minta atau disebut pemungut uang logam kepada pengguna jalan utama kabupaten Banyumas menuju Kota Purwokerto, Purbalingga. Menurut Undang-undang setiap warga Negara berhak hidup layak dan bermartabat. Untuk kondisi tersebut maka penting dilakukan penelitian bertujuan untuk mengetahui upaya Pemerintah Desa Pageralang dalam memecahkan kasus tentang perilaku sosial masyarakat yang menggantungkan diri terhadap pemberian orang lain. Jenis Penelitian ini adalah deskriptif kualitatif. Subjek penelitian ini adalah Pemerintah Daerah, Pemerintah Desa, Tokoh Masyarakat dan Pelaku pemungut. Objek penelitian ini adalah upaya mengatasi perilaku sosial yang bergantung pada orang lain. Metode yang digunakan untuk pengumpulan data adalah wawancara, observasi, dan dokumentasi. Analisis data dilakukan dengan langkah-langkah pengumpulan data, reduksi data, display data dan verifikasi dan penegasan kesimpulan. Hasil penelitian menunjukkan upaya pemerintah sudah memberikan pengarahan yaitu sosialisasi agar tidak lagi malas bekerja dengan membuatkan program pelatihan untuk warga agar mereka mempunyai keterampilan dan dapat membantu perekonomian warga menjadi lebih baik dari menjual hasil dari keterampilan yang mereka buat. Upaya pemerintah di sini sudah dilakukan dengan memberikan pengertian agar warga tidak lagi mempercayai atau menghubungkan dengan mitos-mitos yang sudah beredar sejak dulu. Berbagai upaya pemerintah yang sudah dilaksanakan dalam bentuk sosialisasi, pembinaan, pengertian, razia, himbauan kepada pengendara dan pemungut uang logam dan mediasi secara langsung dari Bupati Banyumas yang langsung menanyakan kepada warga apa yang diinginkan dari warganya agar tidak lagi berada disitu, namun tetap saja tidak membuahkan hasil. Warga pun kembali lagi menjadi pemungut uang logam dan kegiatan tersebut masih ada sampai peneliti melakukan penelitian di Desa Pageralang.
\end{abstract}

Kata kunci: tradisi, pemungut uang logam, desa pageralang, pemerintahan

\begin{abstract}
Pageralang Village, Kemranjen Sub district, Banyumas Regency has a hereditary counter-social tradition of begging or called coin collecting for the main road user of Banyumas Regency to Purwokerto, Purbalingga. According to the Law, every citizen has the right to live correctly and with dignity, for this condition, it is important to conduct research aimed at identifying the efforts of the Pageralang Village Government in solving cases concerning social behavior of people who depend on the giving of others. This type of research is descriptive qualitative. The subjects of this study are the Regional Government, Village Government, Community Leaders, and Collectors. The object of this research is an effort to overcome social behavior that depends on others. The methods used for data collection are interviews, observation, and documentation. Data analysis was carried out with the steps of data collection, data reduction, data display and verification and confirmation of conclusions. The results of the research show that government efforts have provided direction, namely socialization so that they are no longer lazy to work by making training programs for citizens so that they have the skills and can help the citizens' economy become better than selling the results of the skills they make. The efforts of the government here have been carried out by providing understanding so that citizens no longer believe in or relate to the myths that have been circulating for a long time. Various government efforts have been carried out in the form of socialization, guidance, understanding, raids, appeals to motorists and coin collectors and direct mediation from the Banyumas Regent who directly asks citizens what their citizens want from being no longer there, but still not produce results. Residents returned to being coin collectors and the activity was still there until researchers conducted research in the village of Pageralang.
\end{abstract}

Keywords: tradition, collector of coins, pageralang village, government

Copyright (C2020 Universitas Ahmad Dahlan

\section{PENDAHULUAN}

Di sejumlah daerah atau kota-kota besar seperti Jakarta, Bandung, Yogyakarta dan kota- kota besar lainnya juga masih banyak yang melakukan perilaku kontra sosial, yaitu dengan mengemis. Pengemis adalah orang yang mendapatkan penghasilan dengan meminta-minta 
di tempat umum atau ke rumah-rumah dengan tujuan dan kesulitan mencari pekerjaan untuk mengharapkan belas kasih dari orang lain. Sedangkan mengemis adalah sebutan untuk pekerjaan atau kegiatan atau perilaku memintaminta yang dilakukan pengemis. Biasanya hal yang diminta berupa materi seperti uang, pakaian, makanan dan lain-lain (Dimas. 2013). Desa Pageralang Kecamatan Kemranjen Kabupaten Banyumas salah satu daerah yang juga terdapat adanya pengemis. Desa Pageralang Kecamatan Kemranjen Kabupaten Banyumas terdapat banyak potensi sumber dayanya, yang paling menonjol adalah karet. Dulu ada yang memproduksi cengkeh karena ada warga bekerja sebagai buruh cengkeh namun semenjak pabrik cengkeh bangkrut warga menjadi pengangguran, menjadi petani dan melakukan kegiatan kontra sosial yaitu sebagai pengemis ada ketidakseimbangan hak dan kewajiban sosial antara peserta interaksi sosial (pengemis merasa punya hak, tetapi kewajiban diabaikan, sementara pemberi merasa mempunyai kewajiban tetapi haknya tidak diperhatikan). Perilaku sosial yang dimaksud adalah warga sekitar secara turun temurun sudah melakukan hanya karena budaya yang sudah ada sejak dulu dengan cara meminta minta kepada pengguna jalan.

Desa Pageralang Kecamatan Kemranjen Kabupaten Banyumas menjadi jalan utama untuk menuju kota Purwokerto, Purbalingga dan lainnya. Menurut warga jalan di Desa Pageralang memang dikenal dengan suasana mistis, banyak terjadi kecelakaan dan terjadinya kriminalitas. Dengan kejadian seperti itu warga sepakat untuk melakukan upacara sesajen bagi pengguna jalan. Yang awalnya dilakukan seperti upacara sesaji biasa, namun berjalannya waktu upacara sesaji itu berubah karena dianggap mempersulit pengguna jalan, akhirnya upacara sesaji itu diganti menjadi pelemparan uang ke jalanan dari pengguna jalan yang melewati jalan tersebut. Warga Desa Pageralang mempunyai rumah dan pendidikan yang cukup layak. Namun, karena kebiasaan yang sudah mengakar di daerah tersebut menjadikan warga malas bekerja secara layak. Ada beberapa alasan warga untuk melakukan kegiatan perilaku kontra sosial (mengemis). Beberapa diantaranya melakukan kegiatan memungut koin untuk mengisi kekosongan daripada hanya di rumah saja, ada juga yang mengatakan untuk memenuhi kebutuhan sehari-hari. Warga yang ikut dalam kegiatan perilaku sosial (mengemis) itu biasanya dilakukan pukul 08.00-16.00 WIB untuk perempuan, dan kebiasaan ini berlanjut sampai malam harinya untuk laki-laki. Namun ada juga yang datang dari pagi jam 08.00 - 12.00 dan kemudian dilanjutkan oleh pengemis lainnya dari jam 12.00 - 16.00. Para pengemis itu tidak hanya berasal dari desa Pageralang, namun ada juga yang berasal dari desa lain yang ikut memunguti uang yang dilemparkan oleh pengguna jalan.

Pemerintah Kabupaten Banyumas sudah melakukan berbagai upaya untuk menetralisir jalan nasional penghubung Purwokerto-Jogja, masuk Kebun Krumput Desa Pageralang Kecamatan Kemranjen, Banyumas dari aktivitas pengemis. Terkadang Satpol PP menertibkan pengemis untuk diberi pengarahan dan kemudian dipulangkan dengan cara Kepala Desa Krumput yang menjemputnya. Usai Satpol PP melakukan razia, mereka berencana untuk memasang papan larangan mengemis di wilayah tersebut. Tidak hanya itu, pembuatan pagar pembatas jalan hingga himbauan kepada pengendara agar tidak memberi uang juga akan ditempuh. Menurut mereka, rencana tersebut dilakukan untuk menyadarkan warga agar tidak lagi mengemis dijalan. Pihak Satpol PP juga sudah mengatakan bahwa akan melakukan razia sesering mungkin untuk mengawasi kebiasaan warga dijalan.

Perilaku menyimpang adalah perilaku dari warga masyarakat yang dianggap tak sesuai dengan kebiasaan, tata aturan dan norma yang berlaku (Syahrial Syarbani Rusdiyanta, 2009). Menurut Setiadi (2011) penyimpangan terhadap norma-norma atau nilai-nilai masyarakat disebut deviasi (deviation), sedangkan pelaku atau individu yang melakukan penyimpangan disebut devian (deviant). Norma adalah sebuah perangkat yang dibuat untuk mengatur hubungan di dalam suatu masyarakat agar dapat berjalan sebagaimana yang diharapkan. Selain itu semua norma yang dibuat didalam suatu masyarakat pasti akan mengalami yang namanya sebuah proses, sehingga norma-norma tersebut dapat diakui, dihargai, dikenal, hingga ditaati oleh warga masyarakat dalam kehidupan sehari-hari. Disini peneliti menggunakan teori penyimpangan sosial dan norma-norma seperti norma hukum, norma kesusilaan dan norma agama.

\section{METODE}

Penelitian ini menggunakan pendekatan kualitatif untuk mendeskripsikan suatu fenomena yang terjadi. Fenomena tersebut berupa upaya pemerintah Desa Pageralang Dalam Mengatasi Perilaku Sosial Masyarakat Yang Menggantungkan Diri Terhadap Orang Lain. Dalam hal ini, penulis akan mengamati situasi masyarakat Desa Pageralang, Kecamatan Kemranjen, Kabupaten Banyumas, Jawa Tengah, terutama masyarakat desa yang menjadi pemungut uang logam untuk mendapatkan upayaupaya Pemerintah Desa dan sekitar. Subjek 
penelitian adalah masyarakat yang menjadi pemungut di Desa Pageralang Kecamatan Kemranjen Kabupaten Banyumas dan pemerintah setempat yaitu Satuan Polisi Pamong Praja, Kepala TKSK (Tenaga Kesejahteraan Sosial Kecamatan), Kepala Desa, dan tokoh masyarakat.

Sedangkan objek dalam penelitian ini adalah upaya mengatasi perilaku sosial yang bergantung pada orang lain. Agar dapat mengetahui keberhasilan cara mengatasi perilaku sosial yang bergantung pada orang lain.

Teknik pengumpulan data merupakan cara yang digunakan peneliti untuk mendapatkan data yang valid berdasarkan apa yang akan di teliti. Dalam penelitian ini menggunakan tiga teknik dalam mengumpulkan data, yaitu: (a) Wawancara (Interview), dalam penelitian ini wawancara yang digunakan peneliti adalah teknik wawancara semi terstruktur. Tujuannya adalah untuk memperkuat jawaban atau informasi mengenai upaya Pemerintah Desa Pageralang dalam mengatasi perilaku sosial masyarakat yang menggantungkan diri terhadap pemberian orang lain. (b) Observasi yang dilakukan peneliti adalah observasi partisipatif, dimana peneliti ikut terjun langsung dalam kegiatan kemasyarakatan dan kegiatan upaya Pemerintah Desa Pageralang dalam mengatasi perilaku social masyarakat yang menggantungkan diri terhadap pemberian orang lain. (c) Dokumentasi dilakukan peneliti untuk mencari bukti-bukti dokumen pendukung dalam hal upaya Pemerintah Desa Pageralang mengatasi perilaku social masyarakat. Dalam hal ini peneliti mengecek data dengan cara membandingkan hasil data yang diperoleh dari beberapa teknik yaitu, observasi, wawancara, dan dokumentasi.

Menurut Moleong (2016: 3) Penelitian deskriptif kualitatif adalah sebagai prosedur penelitian yang menghasilkan data deskriptif berupa kata-kata tertulis atau lisan dari orangorang dan perilaku yang dapat diamati. Penyajian data dalam penelitian ini mulai dari lokasi penelitian, observasi lapangan sarana prasarana pendukung, serta data-data hasil wawancara. Secara khusus peneliti akan mendeskripsikan upaya Pemerintah Desa Pageralang dalam mengatasi perilaku social masyarakat yang menggantungkan diri terhadap pemberian orang lain.

\section{HASIL DAN PEMBAHASAN}

\section{Penyimpangan sosial}

Perilaku menyimpang adalah perilaku dari warga masyarakat yang dianggap tak sesuai dengan kebiasaan, tata aturan dan norma yang berlaku (Syahrial Syarbani Rusdiyanta. 2009). Dalam Kamus Besar Bahasa Indonesia perilaku menyimpang diartikan sebagai tingkah laku, perbuatan, atau tanggapan seseorang terhadap lingkungan yang bertentangan dengan normanorma dan hukum yang ada di dalam masyarakat. Dalam kehidupan masyarakat, semua tindakan manusia dibatasi oleh aturan (norma) untuk berbuat dan berperilaku sesuai dengan sesuatu yang dianggap baik oleh masyarakat.

\section{Meminta dengan Memaksa}

Meminta dengan memaksa ini adalah adanya tindakan kriminal yang terjadi kepada pengendara yang berada di jalan Krumput. Hal ini dapat dijelaskan bahwa dulu tindakan kriminal seperti perampokan pada pengendara sangat banyak namun dengan adanya warga yang berada di Jalan Krumput sudah mulai berkurang yang sebelumnya banyak terjadi kriminal sekarang sudah tidak ada lagi. Karena pada malam hari banyak laki-laki yang berada di pinggir jalan untuk menemani pengendara dan menjaga yang lewat pada malam hari. Hal ini sebenarnya bisa membantu para pengendara yang pulang atau pun pergi pada malam hari dan di sini warga yang menjadi pemungut uang logam menjadi hal yang positif bukan hal yang terjadinya negative.

Tindakan kriminal atau kejahatan, ini bisa dihubungkan dengan penelitian peneliti karena dulu banyak terjadinya tindakan kriminal perampokan dijalan tersebut. Tindakan kriminal atau kejahatan adalah jenis kejahatan yang tercantum dalam Kitab Undang-undang Hukum Pidana (KUHP), seperti pembunuhan, perampokan, penganiayaan dan lain sebagainya yang disebut sebagai violent offenses (kejahatan kekerasan) dan violent offenses (kejahatan hak milik).

\section{Norma Kesusilaan}

Norma kesusilaan ini dilihat dari hasil penelitian adalah bahwa hasil penelitian tidak ada sanksi yang diberikan melainkan hanya dilakukan pembinaan saja kepada warga. Ini dapat dijelaskan bahwa tidak ada sanksi yang tegas yang diberikan melainkan hanya pembinaan saja karena tidak ada Undang-undang atau Peraturan Daerah yang bisa memberikan sanksi kepada pemungut uang logam mereka berbeda dengan pengemis, gelandangan dan sebagainya. Hal ini sama seperti C.J.T. Kansil yaitu aturan atau pedoman hidup yang dianggap sebagai suara sanubari manusia yang berhubungan langsung dengan baik buruknya sebuah perbuatan. Norma kesusilaan sendiri berasal dari moral serta hati nurani manusia. Pada norma kesusilaan umumnya pemberian sanksi bersifat tidak tegas. 
Ini bisa diperjelas bahwa mereka memang tidak bisa diberikan sanksi oleh Pemerintah karena tidak ada peraturan yang mengaturnya hanya saja mereka mempunyai kebiasaan yang tidak patut dicontoh oleh anak-anak generasi selanjutnya dikhawatirkan mereka mengikuti jejak orang tuanya yang hanya menjadi pemungut uang logam saja.

\section{Norma Agama}

Bahwa belum adanya pemuka agama yang menangani kasus tersebut yang ada hanyalah sesepuh atau kepala suku bukan ustaz yang menangani. Hal ini berbanding terbalik dengan pengertian norma yang ada yaitu pedoman hidup manusia yang sumbernya dipercaya dari Tuhan yang Maha Esa. Norma agama sifatnya dogmatis, yaitu tak boleh dikurangi ataupun ditambah (C.J.T. Kansil). Baik pemerintah Desa maupun Pemerintah setempat tidak ada yang mendatangi pemuka agama seperti ustaz agar tidak terjadi halhal yang diluar batas agama, seperti mengaitkan dengan hal-hal mistis. Namun di dalam dalam norma agama, terdapat sanksi yakni berupa hukuman di alam selanjutnya atau akhirat. Dengan kata lain, norma agama memberikan sanksi secara tidak langsung akan tetapi diberikan setelah manusia meninggal dunia.

\section{Norma Hukum}

Norma hukum di sini yaitu untuk mengetahui apakah ada tindakan secara hukum untuk warga yang melakukan kebiasaan itu dan hasilnya adalah penelitian tidak ada tindakan secara khusus oleh pemerintah. Di sini dapat disimpulkan bahwa tidak ada tindakan secara khusus kepada warga yang melakukan kegiatan itu yang menjadi sebuah kebiasaan yang tidak patut dicontoh oleh anak-anak karena nantinya akan berakibat tidak baik untuk perkembangannya. Namun di sini juga dapat dihubungkan apabila kegiatan tersebut dilakukan secara terus menerus akan mengganggu ketertiban jalan dan akan mengenai tindakan hukum.

Hal itu bisa dihubungkan kedalam pengertian norma hukum menurut C.J.T. Kansil peraturan yang dibuat oleh lembaga-lembaga tertentu yang mempunyai wewenang untuk mengatur kehidupan bermasyarakat, bernegara dan berbangsa. Peraturan ini bersumber pada perundang-undangan, kebiasaan, yurisprudensi dan juga doktrin. Peraturan Daerahnya yaitu NO. 5 TAHUN 2014 bagi pengendara yang melewati Jalan Krumput dilarang melemparkan uang/barang kepada warga yang berada dijalan (pemungut uang logam). Walaupun sudah dibuatkan poster disetiap jalan namun tetap saja pengendara melemparkan uang kepada warga.
Usaha pemerintah sudah banyak dilakukan hanya saja kembali lagi kepada masing-masing warga yang masih menghubungkan kepada hal-hal mistis bukan untuk kebaikan warga itu sendiri.

\section{Profesi}

Profesi yang dimaksud disini adalah mengenai asal usul masyarakat menjadi pemungut uang logam, mulai kapan menjadi pemungut uang logam, pendapatan sehari-hari yang didapat selama berada dipinggir jalan, mempunyai pekerjaan lain selain menjadi pemungut, dan bagaimana pendapat warga lainnya yang tidak ikut menjadi pemungut uang logam. Dari beberapa dari narasumber yang dapat disimpulkan bahwa ada orang yang sudah lama menjadi pemungut uang logam, namun adapun yang belum lama menjadi pemungut uang logam, alasannya juga bermacam-macam. Ada yang mempunyai alas an untuk menemani pengendara yang melewati jalan, agar tidak bosan di rumah dan mempunyai kegiatan, ada yang ikut-ikut temannya dan ada juga yang memang tidak punya pekerjaan selain menjadi pemungut uang logam. Untuk kegiatan tersebut dilakukan mulai dari siang sampai sore hari untuk perempuan dan lakilaki pada malam hari. Warga yang berada dijalan sudah menjadi kebiasaan dengan kepercayaan/mitos bahwa orang yang melemparkan uang disitu akan ditambah rezekinya/bagi pengendara akan selamat. Karena memang dijalan tersebut hutan dan mereka takut kalau terjadi apa-apa maka mereka melemparkan uang. Warga tetap mengaitkan kejadian-kejadian tersebut dengan hal mistis. Dan juga alasan mereka melakukan itu karena adanya tradisi yang turun temurun yang sudah ada dari zaman dulu bahkan sampai berlangsung turun temurun kepada anak cucu (Dimas Dwi Irawan, 2013).

Namun apabila di lihat masyarakat disebut sebagai salah satu penyakit sosial atau penyakit sosial (Patologi Sosial). Segala bentuk tingkah laku dan gejala-gejala sosial yang dianggap tidal sesuai, melanggar norma-norma umum, adat istiadat, hukum formal, atau tidak bisa diintegrasikan dalam pola tingkah laku umum dikategorikan sebagai penyakit social atau penyakit masyarakat (Kartono Kartini, 2009).

\section{Upaya-upaya mengatasi}

\section{Razia}

Razia yang dimaksudkan di sini yaitu untuk menangani masyarakat yang tidak mau mendengarkan himbauan dari Satpol PP (Satuan Polisi Pamong Praja) yang sudah memberikan peringatan atau himbauan kepada masyarakat agar tidak lagi berada di pinggir jalan karena akan 
mengganggu pengguna pengendara dijalan. Seperti yang dijelaskan penangkapan beramairamai; penggerebekan penjahat yang berbahaya bagi keamanan (KBBI). Razia dilakukan tidak setiap saat hanya pada saat hari besar seperti idul fitri dan tahun baru. Mengingat bahwa memang Satuan Polisi Pamong Praja melakukan razia hanya untuk memberikan peringatan kepada warga agak tidak lagi berada di pinggir jalan terlebih pada hari-hari besar karena akan lebih ramai lagi pengendara yang lewat.

Petugas melakukan razia melakukan hal tersebut dengan alasan kesehatan tiap hari berada di pinggir jalan banyak debu dan terkadang hujan menjadi alasan mereka untuk membubarkan masyarakat. Untuk alasan keselamatan yang dikhawatirkan oleh petugas agar tidak terkena musibah seperti kecelakaan dan lainnya dan alasan yang mendukung adalah untuk menjaga ketertiban jalan raya. Namun ada yang berbeda pendapat dengan menjelaskan juga mengenai razia dilakukan apabila ada keresahan/laporan dari pemerintah misalnya ada terjadi tindakan kriminal maka petugas melakukan razia agar menjadi tertib dijalan. Dan dari penjelasan narasumber bisa diartikan tidak hanya keresahan/laporan dari pemerintah saja melainkan ketika ada pejabat yang melewati jalan tersebut dihimbau untuk tidak melakukan aktivitas tersebut, namun apabila masyarakat ada disitu sudah dihimbau untuk tidak melambaikan tangan(tanda meminta) berarti memang masyarakat disitu secara tidak langsung meminta uang kepada pengendara yang lewat seperti yang dijelaskan narasumber.

\section{Program}

Program dari setiap desa itu ada dan masingmasing desa mempunyai program-program yang berbeda-beda. Program tersebu ada di dalam bentuk tertulis maupun tidak. Menurut Kepala Desa Pageralang program di desa berbentuk seperti pelatihan, pelatihan tersebut dilakukan setiap tahun. Namun dari penjelasan narasumber bahwa warga yang menjadi pemungut uang logam berbeda pelatihannya yaitu membuat keset. Kemudian hasil pelatihan tersebut dijual untuk menambah penghasilan bagi warga untuk menambah biaya hidup. Hal ini sama seperti dalam KBBI (Kamus Besar Bahasa Indonesia) bahwa rancangan mengenai asas serta usaha (dalam ketatanegaraan, perekonomian, dan sebagainya) yang akan dijalankan. Hal ini saling berhubungan dengan program yang ada di Pemerintah Kabupaten yang sudah membuatkan program berupa sembako dan lainnya seperti yang dipaparkan oleh Petugas Satpol PP. Di sini masyarakat memang membutuhkan tidak hanya dalam bentuk pelatihan saja biar mempunyai skill namun juga membutuhkan bantuan dalam bentuk sembako karena ada dari mereka yang tidak bisa membeli bahan sembako. Bantuan seperti itu sudah cukup bagi masyarakat apabila dilakukan secara rutin setidaknya untuk membantu pahan pangan masyarakat yang memang benar-benar kekurangan

Namun ini beberapa pendapat lain dari Kepala Petugas TKSK (Tenaga Kesejahteraan Sosial Kecamatan). Menurut penjelasan Petugas Kesejahteraan Sosial Kecamatan tersebut bahwa sampai Bupati Banyumas turun langsung ke Desa Pageralang untuk membagikan sembako bagi warganya dan melakukan mediasi langsung kepada mereka apa keinginan mereka agar tidak lagi menjadi pemungut uang logam karena dari Pemerintah Kabupaten sudah cukup resah dengan beredarnya berita mengenai warga yang menjadi pemungut uang logam. Yang orang-orang tahu warga menjadi pengemis bukan menjadi pemungut maka dari itu dari Pemerintah Kabupaten ingin meluruskan berita yang beredar dan juga ingin memberikan pekerjaan yang lain agar mereka tidak lagi menjadi pemungut. Namun dengan usia warga yang sudah tidak muda lagi (pemungut berusia diatas 45 tahun ke atas) sehingga sulit untuk memberikan pekerjaan yang sesuai dengan mereka dan belum tentu mereka mau untuk bekerja sesuai yang Pemerintah inginkan.

\section{Sosialisasi}

Sosialisasi diberikan dalam bentuk keprihatinan pemerintah terhadap warga Desa Pageralang, agar tidak lagi berada di Jalan Krumput karena rumah yang mereka huni masih dikatakan masih layak untuk dihuni. Berarti dalam wawancara dengan Petugas TSKS (Tenaga Kesejahteraan Sosial Kecamatan) ia lebih mengutamakan untuk memberikan pengertian agar tidak lagi berada disitu dan yang paling penting adalah memberikan pengertian kepada warga yang masih ikut membawa anaknya ke pinggir jalan hal itu akan berdampak tidak baik untuk perkembangan mental dan moral anaknya. Karena hanya melihat orang tuanya berada di pinggir jalan saja sudah bisa mendapatkan uang untuk hari biasa memang tidak terlalu banyak namun pada hari besar seperti idul fitri dan tahun baru pendapatannya akan meningkat lebih besar dari biasanya. Orang-orang yang pada hari biasa tidak terlalu banyak juga akan menambah pada hari besar. Namun tetap di sini warga yang masih membawa anaknya di pinggir jalan akan beresiko tinggi baik dalam perkembangan pertumbuhannya dan kesehatannya yang akan terganggu. Banyaknya debu terkadang juga hujan dan juga 
menimbulkan pemikiran yang ditakutkan oleh Pemerintah Desa dan Pemerintah Kabupaten apabila jejak orang tuanya akan diikuti oleh anaknya nanti.

Sosialisasi dilakukan untuk mengubah pola pikir masyarakat dan bisa mengubah kebiasaankebiasaan yang tidak baik dilakukan untuk kepentingan dan untuk masa depan yang lebih baik kepada masyarakat agar tidak lagi bergantung kepada orang lain yang memungut uang di pinggir jalan hal ini sama halnya dengan pengertian sosialisasi menurut KBBI (Kamus Besar Bahasa Indonesia) usaha untuk mengubah milik perseorangan menjadi milik umum (milik negara) tradisi tidak memperlancar proses perusahaan milik keluarga, proses belajar seorang anggota masyarakat untuk mengenal dan menghayati kebudayaan masyarakat dalam lingkungannya tingkat-tingkat permulaan dari proses manusia itu terjadi dalam lingkungan keluarga, upaya memasyarakatkan sesuatu sehingga menjadi dikenal, dipahami, dihayati oleh masyarakat.

\section{Media Massa}

Memang tidak ada pengaruh dari media massa malah menjadikan Desa Pageralang menjadi eksis dan banyak orang yang mengetahui tentang desanya. Dari penjelasannya Kepala Desa tidak ingin membubarkan warga yang menjadi pemungut, warga yang di sana bisa untuk menemani para pengendara apabila ada kecelakaan, tindakan kriminal atau hal lainnya jadi warga ada membawa hal positif bagi para pengendara terlebih pada malam hari yang memang terlihat sepi pada jalan tersebut. Jika dilihat dari penjabaran narasumber untuk mereka media tidak ada pengaruhnya maka dari itu berbanding terbalik dengan jangkauan media sangat tinggi dan sangat berpengaruh, untuk itu memakan waktu antara masyarakat dan posisi moral. Sikap anti-sosial dan kewajiban media William R. Rivers (2008).

Dari penjelasan narasumber kedua tidak ada pengaruhnya dengan media massa, dulu Desa Pageralang masuk kedalam salah satu stasiun tv namun warga keberatan dengan program tersebut karena mereka menyebutkan bahwa Desa Pageralang menjadi Desa Pengemis hal itu membuat warga tidak suka. Warga yang di Jalan Krumput bukan pengemis hanya saja mereka memungut uang logam yang dilempar oleh para pengendara saja. Namun dari hal itu membuat Desa Pageralang menjadi eksis dan dikenal oleh banyak orang. Mungkin untuk warga menginginkan program tersebut mengubah judul bukan Desa Pengemis melainkan judul yang lainnya itu yang terkadang mengundang pemikiran orang-orang beranggapan memang benar warga menjadi pengemis namun kenyataannya bukan. Hal ini bisa dikaitkan dengan pengaruh media dapat menembus publik umum, karena itu media sering kali disalahkan sebagai kaki tangan untuk mempengaruhi publik atas perilaku anti sosial. Menghadapi kritik tersebut media berusaha untuk lebih memperhatikan hal-hal yang dapat merusak perilaku seseorang yaitu dengan membuat beberapa acuan dan aturan yang membuat media menjadi lebih berkembang dan lebih baik (William R. Rivers, 2008).

\section{KESIMPULAN}

Berdasarkan hasil penelitian, maka dapat disimpulkan bahwa Upaya Pemerintah Desa Pageralang Dalam Mengatasi Perilaku Sosial Masyarakat Yang Menggantungkan Diri Terhadap Pemberian Orang Lain yaitu upaya pemerintah sudah memberikan pengarahan yaitu sosialisasi agar tidak lagi malas bekerja dengan membuatkan program pelatihan untuk warga agar mereka mempunyai keterampilan dan dapat membantu perekonomian warga menjadi lebih baik dari menjual hasil dari keterampilan yang mereka buat. Namun peran Pemerintah juga ikut membantu warga untuk menjualkan hasil karya dari pelatihan yang sudah diadakan agar mereka tidak terhambat dan mampu untuk menjual hasil dari karya mereka.

Upaya pemerintah sudah dilakukan dengan memberikan pengertian agar warga tidak lagi mempercayai atau menghubungkan dengan mitosmitos yang sudah beredar sejak dulu. Tetapi warga tetap saja tidak mengimbaunya dan tetap menghubungkan atau mempercayai mitos tersebut sampai saat ini. Untuk itu upaya yang dilakukan oleh Pemerintah memang belum berhasil membuat warga agar tidak lagi percaya dengan mitos tapi apabila dari Pemerintah tetap memberikan pengertian tersebut dan memberikan pengalihan kepada mereka warga akan secara tidak langsung untuk berhenti menjadi pemungut uang logam.

Berbagai upaya pemerintah yang sudah dilaksanakan dalam bentuk sosialisasi, pembinaan, pengertian, razia, himbauan kepada pengendara dan pemungut uang logam dan mediasi secara langsung dari Bupati Banyumas yang langsung menanyakan kepada warga apa yang diinginkan dari warganya agar tidak lagi berada disitu, namun tetap saja tidak membuahkan hasil. Warga pun kembali lagi menjadi pemungut uang logam dan kegiatan tersebut masih ada sampai peneliti melakukan penelitian di Desa Pageralang. 


\section{DAFTAR PUSTAKA}

Arikunto, Suharsimi. 2000. Prosedur Penelitian Suatu Pendekatan Praktek. Jakarta: PT Renika Cipta

Arikunto, Suharsimi. 2006. Prosedur Penelitian Suatu Pendekatan Praktek. Jakarta: PT Renika Cipta

Dimas. 2013. Pengemis Undercover: Rahasia Seputar Kehidupan Pengemis. Cibubur: Titik Media Publisher.

https://www.academia.edu/17091204/KONTR OL_SOSIAL_atau_PENGENDALIAN_SO SIAL

Kamus Besar Bahasa Indonesia. 2012. Pusat Bahasa Departemen Pendidikan Bahasa

Kartono, Kartini. 2009. Patologi Sosial Jilid 1. Jakarta: Rajawali Pers

Muin, Idianto. 2013. Sosiologi untuk SMA/MA Kelas X. Kelompok Peminatan Ilmi-Ilmu Sosial. Jakarta: Erlangga

Sugiyono. (2010). Metode Penelitian Pendidikan (Pendekatan Kuantitatif, Kualitatif, dan R \& D). Bandung: Alfabeta.

Sugiyono. (2013). Metode Penelitian Pendidikan (Pendekatan Kuantitatif, Kualitatif, dan R \& D). Bandung: Alfabeta.

Sugiyono. (2015). Metode Penelitian Pendidikan (Pendekatan Kuantitatif, Kualitatif, dan R \& D). Bandung: Alfabeta.

Sukmayati, Ratna dkk. 2008. Ilmu Pengetahuan sosial. Jakarta: Pusat Perbukuan Departemen Pendidikan Nasional 